\title{
THE EFFECT OF OCCUPATIONAL SAFETY AND HEALTH AND WORK DISCIPLINE ON EMPLOYEE PERFORMANCE IN THE ENVIRONMENTAL SERVICES OF YOGYAKARTA CITY
}

\author{
M. Hibbul Watoni \\ Faculty of Economic and Business, Sebelas Maret University \\ Email: hibbul.watoni@gmail.com
}

\begin{abstract}
This study aims to investigate the effect of occupational safety and health and work discipline on employee performance in the Environmental Services of Yogyakarta City either partially or simultaneously. The population of this study was 220 employees of the Sanitation Division in the Environmental Services of Yogyakarta City. The current study involved 135 samples who were selected using a random sampling technique. It used primary data and they were collected through distributing a questionnaire. The validity and reliability of the questionnaire have been tested prior to the administration. Then, the data were analyzed by multiple linear regression analysis, t-test, f-test, and determination test using SPSS 20. The result showed that partial testing of occupational safety and health (X1) and work discipline (X2) variables had a significant effect on employee performance (Y) in the Environmental Services of Yogyakarta City. Whereas simultaneous testing of Occupational safety and health (X1) and work discipline (X2) variables significantly affected the employee performance (Y) in the Environmental Services of Yogyakarta City.
\end{abstract}

Keywords: Occupational safety and health, Work Discipline, Employee Performance

\section{Introduction}

Based on the provisions of Law Number 13 of 2003 concerning Manpower, every company has to implement efforts to ensure occupational safety and health by protecting the safety of workers and production facilities. In accordance with the Labour Law Number 13 of 2003 article 87 (1) stipulates that every type of business has to possess an integrated occupational safety and health system in the company's management system. The company has responsibilities to provide instructions, training, and supervision to ensure the occupational safety and health of its employees. The occupational safety and health (K3) is an essential aspect that needs to be taken into account in the company's management system, either private or state-owned companies as it deals with activities that protect and maintain the company's resources or assets.

However, work discipline also has to be possessed by employees as it is always expected to be the prominent characteristic of each human resource in the organization. Through discipline, the organization will run well and manage to achieve its goals. Hence, the employees' awareness of work discipline is highly required. The work in the field of sanitation has to be performed carefully and the employees have to use the tools appropriately based on the standard operating procedures set by the company. When the employees are disciplined, then it will make them feel comfortable and in the end, it may improve their performance.

Employees' performance is a key issue in an organization as to whether the organization or company able to achieve its goals or not, it depends on the employee's performance. Thus, in 
implementing employees' performance management, the company has to be able to integrate its own goals with the employees' goals.

Environmental Services of Yogyakarta City is a government agency responsible for monitoring the environment, building capacity, improving beauty and hygiene. In this case, the Sanitation Division of this agency has responsibilities in managing the waste. This division has two important tasks namely transporting waste and city sanitation. This agency has provided complete equipment for fieldworkers (garbage transporters and road cleaners). The fieldworkers have high risks of workplace accidents and work-related health problems. Therefore, all employees in this field have to be disciplined to use all equipment to minimize the risks.

\section{Theoritical Background}

\subsection{Occupational safety and health}

Occupational safety and health and environmental protection are efforts to create safe, comfortable, and healthy workplaces. Therefore, it can minimize or eliminate the risks of workrelated accidents and diseases caused by work that in the end may improve the employees' efficiency and performance.

The basic form of the word 'safety' is 'safe'. It is associated with the condition in which ones free from accidents. Ridley (2008) states that occupational safety means the process of planning and controlling situations that have the potential to cause work-related accidents by preparing standard operating procedures as a reference for work. Widodo (in Silalahi and Rumondang, 2015) states that safety refers to an effort to prevent any unsafe acts or conditions that can result in accidents. He proposed four aspects supporting occupational safety, such as:

a. The presence of occupational safety aspects,

b. Awareness in maintaining occupational safety and health,

c. Work thoroughly, and

d. Performing work procedures by considering health and safety.

Kesehatan which refers to 'healthy' in English does not only mean when someone has no disease, but the notion of 'healthy' means physically, mentally, and socially healthy. Occupational health refers to freedom from physical violence. Health risks are factors in the working environment including working overtime, stress, emotions, or physical disturbance (Mondy and Noe, 2005). Sucipto (2014) proposes some functions of occupational health in the company, namely:

a. Identification and assessment of health risks in the workplace.

b. Providing advice on planning and organizing, and work practices including workplace design.

c. Providing advice, information, training, and education regarding occupational health and Personal Protective Equipment (APD).

d. Conducting surveys on occupational health.

e. Engagement in the rehabilitation process.

f. Managing first aid and emergency measures.

Jackson et all. (2011) states that "Occupational safety and health are concerned with protecting the physical and psychological conditions of workers ". K3 is a multidisciplinary science concerning maintaining and improving the working environment, occupational safety, employees' health, and safety as well as protect them against the dangers of performing the work and prevent losses due to work-related accidents, occupational diseases, fires, blasting or 
pollution in the working environment. Mangkunegara (2005) added that K3 is thoughts and efforts to assure the protection of employees' physical and psychological conditions in particular and humans in general to realize fair and prosperous communities. Meanwhile, Mathis and Jackson (2002) argue that safety refers to the protection of physical well-being against workrelated injuries, while health refers to general physical, mental, and emotional stability.

The aim of applying K3 is to minimize or prevent accidents causing injuries or material loss. The goals of occupational safety and health according to Lamm, Massey \& Perry (2006) are providing a secure and comfort for employees working at any types and levels of work; creating a safe, healthy, and prosperous community; and creating workplaces which are free from hazards or work-related injuries/diseases; and increase productivity. Furthermore, there are some benefits of implementing an occupational safety and health program in the company as proposed by Mondy (2008). They are:
a. Reducing Absenteeism,
b. Reducing Cost of Health Claims,
c. Reducing Employees Turnover,
d. Increasing Productivity.

\subsection{Work Discipline}

Work discipline is crucial for organizational development particularly to motivate employees in working both individually and in groups. Discipline reflects individuals' sense of responsibility towards their tasks. Heidjrachman and Husnan, 2002 (in Sinambela, 2016) state that discipline refers to individuals or groups comply with regulation/orders and initiate to take action if required.

David in Mangkunegara (2001) states that work discipline can be interpreted as the implementation of management to strengthen organizational guidelines. Further, Siagian (2004) asserts that discipline is a management action to encourage members of the organization to meet the demands of various provisions. Discipline according to Hasibuan (2001) is individuals' awareness and willingness to obeys all company regulations and applicable social norms. In this case, awareness refers to attitude to voluntarily obey all the rules and aware of own duties and responsibilities. Employee discipline can be seen based on the following aspects (Mangkuprawira and Hubeis, 2007):

a. Discipline as an aspect of company culture.

b. Discipline related to the possibility of distortion or issues regarding company performance.

c. It arises due to employees' self-awareness or coercion.

d. The employees' motive to be recognized as a good person or an employee model.

e. Not all employees have a hundred percent degree of discipline as there are internal and external factors.

f. Employee discipline is not always related to work productivity, implying that discipline has to be completed with intelligence.

g. Companies' actions in giving rewards to employees.

h. Employee discipline relates to career opportunities

\subsection{Employee Performance}

Performance comes from the word of job performance or actual performance achieved by individuals. Performance (work performance) refers to results of work either the quality or quantity achieved by employees in performing their duties and responsibilities. According to the behavioral approach in management, performance is quantity or quality of products or services 
Vol-3, Issue-4, 2019 (IJEBAR)

E-ISSN: 2614-1280 P-ISSN 2622-4771

https://jurnal.stie-aas.ac.id/index.php/IJEBAR

produced by employees (Luthans, 2011). As translated by HarbaniPasolong, Robbins states "Performance is the result of the evaluation of the work performed by employees compared to predetermined criteria," (Pasolong, 2007). Added to this, Moeheriono (2012) defines performance as a description of achievement level on the implementation of a program or policies in achieving goals, objectives, vision, and mission of the company as outlined in the company's strategic plans.

Mangkunegara (2005) mentions three factors affecting employee performance:

a. The individual factor covers capabilities and expertise, background, and demographics.

b. The psychological factor covers perception, attitude, personality, learning, and motivation

c. The organizational factor covers resources, leadership, rewards, structure, and job design.

\section{Method}

\subsection{Population, Sampling Selection, Sample}

Sugiyono (2014) defines a population as a generalization area consisting of objects/subjects with certain qualities and characteristics determined by the researcher to be examined and then concluded. The population of the current study was fieldworkers in the Sanitation Division of Environmental Services of Yogyakarta City with a total of 220 fieldworkers.

The study applied the Random Sampling technique in which the samples were selected without considering the level of the population (Sugiyono, 2014). The current study involved 135 respondents consisting of fieldworkers in the Sanitation Division of Environmental Services of Yogyakarta City.

\subsection{Types of Data, Source of Data, and Data Collection Technique}

This study used cross-sectional data as it only collected data during the fieldwork (Ghozali, 2009). The source of data was primary data which was gained directly from the respondents. The data were collected through distributing the questionnaire.

\subsection{Testing Variables}

Variables are any items set by the researcher to be examined to get information about them and then discussed and concluded (Sugiyono, 2014).

1. Dependent Variables

Sugiyono (2014) states that dependent variables are often referred to as output variables, criterion or consequent. The dependent variable of the current study was performance (Y) which was measured by a questionnaire. Mangkunegara (2009) propose indicators of performance covering quality, quantity, task implementation, and responsibilities.

2. Independent Variables

Sugiyono (2014) states that independent variables are often referred to as stimulus, predictor or antecedent. This study applied two independent variables namely occupational safety and health (X1) and work discipline (X2).

As stated earlier, Sinambela, 2016 (in Mangkunegara, 2002) highlights that occupational safety and health (K3) thoughts and efforts to assure the protection of employees' physical and psychological condition in particular and humans in general to realize fair and prosperous communities. Gary Dessler (1997) proposed indicators of health in occupational health, namely:

a. Employees' conditions are conditions experienced by employees that support their work. 
International Journal of Economics, Business and Accounting Research (IJEBAR)

Peer Reviewed - International Journal

Vol-3, Issue-4, 2019 (IJEBAR)

E-ISSN: 2614-1280 P-ISSN 2622-4771

https://jurnal.stie-aas.ac.id/index.php/IJEBAR
b. The working environment is a wider environment of the workplace that supports the
employees' work
c. Employee protection is a facility provided by the company to support employee welfare.

Work discipline is the employees' capability to work regularly and continuously in accordance with the applicable regulations/rules (Sinambela, 2016). The indicators of work discipline cover: timeliness, neat clothes, compliance with rules, and responsibility.

\section{Data Analysis And Discussion \\ a. Testing The Research Instrument}

The questionnaire was tested before the fieldwork to see its validity and reliability. It was tested to 30 respondents and then the results were analyzed using SPSS version 20 for Windows.

\section{Validity Test}

The validity of the questionnaire was tested. A valid questionnaire can measure what will be measured. In other words, it was to check whether the designed questions in the questionnaire can measure what will be measured (Adhila, Fitriani, and Ismanto, 2014). If the value of rcount $>$ r-table, then it can be said that the items of questions are valid.

Table 1. Validity Test for Occupational Safety and Health Variables

\begin{tabular}{|c|c|c|c|}
\hline Item & r-count & r-table & Notes \\
\hline Statement 1 & 0,583 & 0,374 & Valid \\
\hline Statement 2 & 0,802 & 0,374 & Valid \\
\hline Statement 3 & 0,768 & 0,374 & Valid \\
\hline Statement 4 & 0,392 & 0,374 & Valid \\
\hline Statement 5 & 0,536 & 0,374 & Valid \\
\hline Statement 6 & 0,540 & 0,374 & Valid \\
\hline Statement 7 & 0,845 & 0,374 & Valid \\
\hline Statement 8 & 0,768 & 0,374 & Valid \\
\hline Statement 9 & 0,548 & 0,374 & Valid \\
\hline Statement 10 & 0,764 & 0,374 & Valid \\
\hline Statement 11 & 0,496 & 0,374 & Valid \\
\hline Statement 12 & 0,485 & 0,374 & Valid \\
\hline Statement 13 & 0,845 & 0,374 & Valid \\
\hline
\end{tabular}

Source: Primary Data, processed (2019)

Table 2. The Validity Test for Work Discipline Variable

\begin{tabular}{|c|c|c|c|}
\hline Item & r-count & r-table & Notes \\
\hline Statement 1 & 0,561 & 0,374 & Valid \\
\hline Statement 2 & 0,502 & 0,374 & Valid \\
\hline Statement 3 & 0,592 & 0,374 & Valid \\
\hline Statement 4 & 0,503 & 0,374 & Valid \\
\hline Statement 5 & 0,784 & 0,374 & Valid \\
\hline Statement 6 & 0,548 & 0,374 & Valid \\
\hline
\end{tabular}


International Journal of Economics, Business and Accounting Research (IJEBAR)

Peer Reviewed - International Journal

Vol-3, Issue-4, 2019 (IJEBAR)

E-ISSN: 2614-1280 P-ISSN 2622-4771

https://jurnal.stie-aas.ac.id/index.php/IJEBAR

\begin{tabular}{|c|c|c|c|}
\hline Statement 7 & 0,503 & 0,374 & Valid \\
\hline \multicolumn{2}{|l}{ Source: Primary Data, processed (2019) }
\end{tabular}

Table 3. Validity Test for Employees' Performance

\begin{tabular}{|c|c|c|c|}
\hline Item & r-count & r-table & Notes \\
\hline Statement 1 & 0,855 & 0,374 & Valid \\
\hline Statement 2 & 0,776 & 0,374 & Valid \\
\hline Statement 3 & 0,855 & 0,374 & Valid \\
\hline Statement 4 & 0,500 & 0,374 & Valid \\
\hline Statement 5 & 0,855 & 0,374 & Valid \\
\hline Statement 6 & 0,776 & 0,374 & Valid \\
\hline Statement 7 & 0,673 & 0,374 & Valid \\
\hline Statement 8 & 0,618 & 0,374 & Valid \\
\hline
\end{tabular}

Source: Primary Data, processed (2019)

\section{Reliability Test}

Reliability is a tool to measure a questionnaire as an indicator of a variable or construct (Adhila, Fitriani, and Ismanto, 2013). A questionnaire is reliable if people give consistent responses to the questions from time to time. The reliability was tested by the Cronbach Alpha $(\alpha)$. A variable will be said reliable if it has a Cronbach Alpha value of $>0.60$. The results of the reliability test for occupational safety and health, work discipline, and employee performance can be seen below.

Table 4. Reliability Test

\begin{tabular}{|l|c|c|}
\hline \multicolumn{1}{|c|}{ Variables } & Cronbach Alpha & Notes \\
\hline Occupational safety and health & 0.913 & Reliable \\
\hline Work discipline & 0.809 & Reliable \\
\hline Employees' performance & 0.905 & Reliable \\
\hline
\end{tabular}

Source: Primary Data, processed (2019)

Based on the table above, it can be seen the value of Cronbach Alpha for each variable was $>0.60$. Hence, it can be concluded that all variables used in this study are reliable.

\section{Multiple Regression Analysis}

Multiple regression analysis was to analyze the influence between occupational safety and health variables and work discipline on employees' performance in the Environmental Services of Yogyakarta City.

Table 5. Summary of Multiple Regression Analysis Result

\begin{tabular}{|c|c|c|c|}
\hline Variable & Coefficient & T-count & Sign \\
\hline Constant & 3.955 & 2.806 & 0.006 \\
\hline Occupational safety and health & 0.346 & 8.329 & 0.000 \\
\hline Work discipline & 0.373 & 5.508 & 0.000 \\
\hline F-count & 183.509 & \multicolumn{2}{l}{} \\
\hline R Square & 0.808 & Sign0.000 \\
\hline
\end{tabular}

Source: Primary Data, processed (2019) 
Based on the results of SPSS 20 for windows, it can be seen that the multiple linear regression equation is:

$$
\mathrm{Y}=3.955+0.346 \mathrm{X} 1+0.373 \mathrm{X} 2
$$

a. The constant value of 3,955 states if there is no occupational safety and health (X1) and work discipline (x2) variables, then the employee performance value (y) is 3,955.

b. The regression coefficient value of X10.346 states if there is an increase of a unit in occupational safety and health variable, the employees' performance will increase by 0.346 .

c. The regression coefficient value of X2 0.373 states if there is an increase of a unit in the work discipline variable, then the employee performance will increase by 0.373 .

\section{T-test}

a. The First Hypothesis

H01: there is no effect of occupational safety and health on employees' performance.

Ha1: there is an effect of occupational safety and health on employee performance.

The results of the significance test of occupational safety and health variable (X1) on employees' performance (Y), with a significance level value of $\alpha=0.05$ with $\mathrm{df}=$ (amount of data-2), $135-2=133$, then the value of t-table was 1.978 with t-count of 8,329. Based on these calculations, it indicated that $\mathrm{t}$-count $=8,329>\mathrm{t}$-table $=1,978$. It means occupational safety and health have a significant effect on employees' performance or $\mathrm{H} 0$ is rejected.

Based on the result of data analysis, it showed that there was a significant influence between occupational safety and health with a probability value of $=0.000<\alpha=0.05$, then $\mathrm{H} 0$ is rejected.

b. The Second Hypothesis

H02: there is no effect of work discipline on employees' performance.

Ha2: there is an effect of work discipline on employees' performance.

The result of significance test for occupational safety and health variables (X3) on employees' performance (Y) showed a significance level value of $\alpha=0.05$ with $\mathrm{df}=$ (amount of data-2), 135-2 = 133 with the value of t-table $=1,978$ and $\mathrm{t}$-count of 5,508. It showed that $\mathrm{t}$-count $=5.508$ was higher than $>\mathrm{t}$-table $=1.978$. Then, the work discipline variable has a significant effect on employees' performance or $\mathrm{H} 0$ is rejected.

It can be concluded that the results of data analysis revealed a significant influence for work discipline with a probability value of $=0.000<\alpha=0.05$, or H0 was rejected.

\section{F-test}

The results of significance test between the occupational safety and health, work stress, and work discipline and employees' performance in the Environmental Services of the Yogyakarta City revealed a level of confidence value of $\alpha=0.05$ and df (degrees of freedom) $=$ 133 with F-count value of 183.509 and F-table value of 2.67. It showed that F-count was higher than F-table $(183.509>2.67)$. It indicated that occupational safety and health, and work discipline have a significant effect on the employees' performance in the Environmental Services of Yogyakarta City. In other words, Ha was accepted.

Furthermore, the sign-count value of $0,000<$ alpha $(\alpha)=0.05$ showed that occupational safety and health, work stress, and work discipline variables had a significant effect on 
Peer Reviewed - International Journal

Vol-3, Issue-4, 2019 (IJEBAR)

E-ISSN: 2614-1280 P-ISSN 2622-4771

https://jurnal.stie-aas.ac.id/index.php/IJEBAR

employees' performance.

\section{Coefficient of Determination Test $\left(\mathbf{R}^{2}\right)$}

The coefficient of determination $\left(\mathrm{R}^{2}\right)$ indicated a value of 0.808 for this current study. In this case, $80.8 \%$ of the employees' performance of the Environmental Services of the Yogyakarta City could be explained by independent variables namely occupational safety and health, and work discipline, while the rest or $19.2 \%$ were explained by other variables.

\section{Discussion}

1. The effect of occupational safety and health on the employees' performance in the Environmental Service of Yogyakarta City

The result of the study revealed $t$-count value of $8,329>\mathrm{t}$-table value of 1,978 with sign $=$ $0,000<\alpha=0.05$. In this case, occupational safety and health had a positive and significant impact on employees' performance. This result is consistent with the finding of a study conducted by Ilfani (2013) in which occupational safety and health have a positive and significant effect on employee performance.

2. The effect of work discipline on the employees' performance in the Environmental Service of Yogyakarta City

The result of the current study showed t-count value of $5.508>\mathrm{t}$-table value of 1.978 with sign $=0.000<\alpha=0.05$. In this case, the work discipline had a positive and significant impact on employees' performance. It is in line with the result of a study conducted by Prawatya (2012) in which work discipline has a positive and significant effect on employees' performance.

3. The effect of occupational safety and health, and work discipline on the employees' performance in the Environmental Service of Yogyakarta City

The result of this study showed a simultaneous effect of occupational safety and health, job stress, and work discipline on the employees' performance in the Environmental Services of Yogyakarta City. It was based on F-count value of 183.509> F-table value of 2.67 with sign-count value of $0.000<$ alpha $(\alpha)=0.05$.

This study showed the coefficient of determination $\left(R^{2}\right)=0.808$ and the effect of occupational safety and health, and work discipline on the employees' performance in the Environmental Services of Yogyakarta City reached a value of $80.8 \%$, while the rest or $19.2 \%$ was explained by other variables besides occupational safety and health, and work discipline.

\section{Conclusion And Recommendation}

a. Conclusion

Based on data analysis and discussion, it can be concluded that:

1. Occupational safety and health have a significant effect on employees' performance.

2. Work discipline has a significant effect on employees' performance.

3. Occupational safety and health, and work discipline simultaneously affect the employees' performance.

b. Recommendation

Based on the discussion and conclusions above, the researcher made the following recommendations for:

1. Environmental Services 
a. Based on the results of the study, we know variables of occupational safety and health and work discipline which affect the employees' performance. Thus, it is expected to continue to improve employees' performance through maintaining occupational safety and health, and work discipline.

b. Environmental Services is expected to provide more training on occupational safety and always remind the importance of maintaining safety and health, work discipline, and avoiding stress at work.

\section{Further Studies}

a. This study only used three variables. Therefore, further studies are expected to add more factors that affect employees' performance.

b. The measurement of the employees' performance has to be done by leaders/superiors or other employees.

c. The population of this study only covered one field, then future studies are expected to increase the number of populations to get results which are closer to the actual conditions.

\section{References}

Adhila, Fitroh. Dyah Fitriani dan Deny Ismanto. 2013. Modul Praktikum Statistik 2. Yogyakarta : Program Studi Manajemen Fakultas Ekonomi Universitas Ahmad Dahlan.

Dessler, Gary. 1997. Management Sumber Daya Manusia. Terjemahan. Benyamin Molan. Edisi Bahasa Indonesia. PT. prenhallind. Jakarta.

Ghozali, Imam. 2009. “Aplikasi Analisis Multivariate dengan Program SPSS”. Semarang: UNDIP.

Hasibuan, Malayu S. P. 2001.Manajemen Sumber Daya Manusia. Jakarta: Bumi Aksara.

Heidjrachma, dan Husnan, Squad. 2002. Manajemen Personalia. Penerbit: BPFE. UGM. Yogyakarta.

Ilfani, Grisma. 2013. Analisis Pengaruh Keselamatan dan Kesehatan Kerja Terhadap Kinerja Karyawan.Skripsi.Semarang : Universitas Diponegoro.

Jackson, Randall S Schuler dan Steve Werner, 2011. Pengelolaan Sumber Daya Manusia edisi kesepuluh. Jakarta: Salemba Empat

Kurniawati, Indah. 2006. Modul Pengolahan Data Elektronik Mengolah Data Statistik dengan SPSS 11.5. Yogyakarta: Univeritas Ahmad Dahlan.

Suma'mur, 1996. Keselamatan Kerja dan Pencegahan Kecelakaan. Jakarta: PT. Toko Gunung Agung

Luthans, Fred. 2011. Organizational Behavior. New York: McGraw-Hill.

Malthis, Robert. L dan Jackson, John H. (2002). Manajemen Sumber Daya Manusia. Jakarta: Salemba Empat.

Mathis, R.L. \& J.H. Jackson. 2006. Human Resource Management: Manajemen Sumber Daya Manusia. Terjemahan Dian Angelia. Jakarta: Salemba Empat.

Mangkunegara, Prabu, 2001. Manajemen Sumber Daya Manusia Perusahaan. Bandung: PT Remaja Rosdakarya

Mangkunegara, Anwar Prabu. 2002. Manajemen Sumber Daya Manusia Perusahaan. Bandung : Remaja Rosda Karya.

Mangkunegara, Anwar Prabu. 2005. Evaluasi Kinerja SDM.Bandung: Refika Aditama.

Mangkunegara, Anwar Prabu. 2009. Manajemen Sumber Daya Manusia Perusahaan. Bandung : 


\section{Remaja Rosda Karya.}

Mangkuprawira, Shafr, dan Hubeis, Aida Vitalaya. Manajemen Mutu Sumbar Daya Manusia. Jakarta: Ghalia Indonesia.

Mondy, R dan Robert M. Noe. 2005. Humam Resorce Management .9th edition. New Jersey: pearson prentice hall.

Mondy, R Wayne, 2008. Manajemen Sumber Daya Manusia edisi kesepuluh. Jakarta: Erlangga.

Moeheriono. 2012. "Pengukuran Kinerja Berbasis Kompetensi". Jakarta: Raja Grafindo Persada.

Nitisnito. S Alex. (2002). Manajemen Personalia Edisi Revisi. Jakarta: Ghalia Indonesia.

Pasolog, Harbani. 2007. Teori Administrasi Publik, Alfabeta, Bandung.

Prawatya, Dipta Adi. 2012. Pengaruh Disiplin Kerja dan Budaya Organisasi Terhadap Kinerja

Karyawan Pabrik Minyak Kayu Putih (PMKP) di krai Purwodadi.Skripsi.Semarang : Universitas Diponegoro.

Ridley, John, 2008. Kesehatan dan Keselamatan Kerja (Ikhtisar) edisi ketiga. Jakarta: Erlangga

Rivai, Veithzal, 2004. Manajemen Sumber Daya Manusia untuk Perusahaan. Jakarta: Raja Grafindo Pustaka

Robert L. Mathis dan John H. Jackson. 2002. Manajemen Sumber Daya Manusia. Jakarta: Salemba Empat.

Saydam, Gouzali. 2005. Manajemen Sumber Daya Manusia: Suatu Pendekatan Mikro. Jakarta: Djambaran.

Setiawan, Heru. 2009. Pengaruh Budaya Organisasi dan Program Keselamatan Kesehatan Kerja (K3) pada Produktivitas Karyawan PT KAI Bandung. Jurnal Trikonomika Vol.8, No.1 Juni.

Siagian, Sondang P., (1994), Patologi Birokrasi, Analisis Identifikasi dan Terapinya, Ghalia Indah, Jakarta.

Simamora, Henry. 2004. Manajemen Sumber Daya Manusia. Yogyakarta : STIE YKPN.

Simanjuntak, Payaman J. (2003), Manajemen dan Evaluasi Kinerja, Jakarta: Lembaga Penerbit Fakultas Ekonomi-Universitas Indonesia.

Sinambela, Lijan Poltak. 2016. Manajemen Sumber Daya Manusia, mambangun Tim Kerja yang Solid untuk Meningkatkan Kinerja.Jakarta : PT Bumi Aksara.

Sucipto, Cecep Dani. 2014. Keselamatan dan Kesehatan Kerja. Yogyakarta : Gosyen Publishing.

Sugiyono. 2014. Metode Penelitian Bisnis. Bandung : Alfabeta.

Suma'mur, 1996. Keselamatan Kerja dan Pencegahan Kecelakaan. Jakarta: PT. Toko Gunung Agung

Terry, GR. 1993. Pengembangan Sumber Daya Manusia. Yogyakarta: Liberty.

Wardoyo Wijayati T.D. (2016). "The Influence of the Discipline and Compensation against Work Productivity (Study on the Security Services Company, PT Garuda Milky Artha Surabaya)". Journal of Business and Management; Vol. 11, No. 1; 2016

Widodo, Suparno Eko. 2015. Manajemen Pengembangan Sumber Daya Manusia. Yogyakarta: Pustaka Pelajar.

Yanuar Rezkyan, Moch. 2013. The Influence of Realization Safety and Healty Work to Work Productivity Employees at PT PLN Jawa Barat and Banten. International Journal of Science and Research (IJSR). ISSN : 2319-7064. 